\title{
HAKEKAT TANGGUNGJAWAB PENGGUNA ANGGARAN DALAM TINDAK PIDANA KORUPSI
}

\author{
Elvis Djusli Katuwu \\ Mahasiswa Program Pascasarjana Universitas Muslim Indonesia Makassar \\ email : elvisdjusli.katuwu@ymail.com
}

\begin{abstract}
Budget User (PA) can not be, mutatis mutandis, or immediately seated as suspect/defendant in a corruption case, because the error position, is an act contrary to the legality of the acts of officials which is based on authority, porsedur and substance. Budget User Officials act is an act of administrative and criminal use is ultimum Remedium. Legal responsibility for the Budget Authority granted to the Budget Users: a. The budget user accountability, whether as mandated by the law that was given to him as KPA, or stages in Presidential Decree No. 80 Year 2003 concerning Procurement of Government Goods and Services, (2) The authority is bound, where all procedures have been done, so the PA there is no reason to not be able to do. (3) The thoroughness in considering the law, if there is an emergency or urgent situations.
\end{abstract}

Keywords: User Responsibility Budget, Corruption.

\begin{abstract}
Abstrak
Pengguna Anggaran (PA) tidak dapat, mutatis mutandis, atau langsung duduk sebagai tersangka / terdakwa dalam kasus korupsi, karena posisi kesalahan, merupakan tindakan yang bertentangan dengan legalitas tindakan pejabat yang didasarkan pada kewenangan, porsedur dan substansi. Tindakan Pejabat Pengguna Anggaran adalah tindakan penggunaan administratif dan kriminal adalah Remedium ultimum. Tanggung jawab hukum untuk Otoritas Anggaran yang diberikan kepada Pengguna Anggaran: a. Pertanggungjawaban pengguna anggaran, baik sebagaimana diamanatkan oleh undang-undang yang diberikan kepadanya sebagai KPA, atau tahapan dalam Keputusan Presiden No. 80 Tahun 2003 tentang Pengadaan Barang dan Jasa Pemerintah, (2) Otoritas terikat, di mana semua prosedur telah selesai, jadi PA tidak ada alasan untuk tidak bisa melakukan. (3) Ketelitian dalam mempertimbangkan hukum, jika ada situasi darurat atau mendesak.

Kata kunci: Pertanggungjawaban; pengguna anggaran; korupsi;
\end{abstract}

\section{A. PENDAHULUAN}

Pengelolaan keuangan negara memasuki era baru setelah diundangkannya, yaitu Undang-Undang Nomor 17 Tahun 2003 tentang Keuangan Negara (UUKN), UndangUndang Nomor 1 Tahun 2004 tentang Perbendaharaan Negara (UUPN) dan UndangUndang Nomor 15 Tahun 2004 tentang Pemeriksaan Pengelolaan dan Tanggung Jawab Keuangan Negara (UU PPTJKN). Ketiga undang-undang tersebut, mengatur hal baru, antara lain adalah adanya check and balance dalam pengelolaan keuangan negara mulai di tingkat perencanaan sampai dengan pelaksanaannya.

Vol. 19 No. 1 Mei 2017 
Pasal 6 ayat (1) UUKN, menyebutkan bahwa "Presiden selaku Kepala Pemerintahan memegang kekuasaan pengelolaan keuangan negara sebagai bagian dari kekuasaan pemerintahan"

Ketentuan di atas, memberi kewenangan kepada Presiden selaku pemegang kekuasaan dalam pengelolaan keuangan negara. Dalam pelaksanaan kewenangan tersebut, Presiden mengdelegasikannya kepada pejabat di bawahnya, yaitu:

1. Menteri Keuangan selaku pengelola fiskal dan wakil Pemerintah dalam kepemilikan kekayaan negara yang dipisahkan. Menteri Keuangan juga menjabat sebagai Bendahara Umum Negara.

2. Menteri/pimpinan lembaga selaku Pengguna Anggaran/Pengguna Barang kementerian negara/lembaga yang dipimpinnya.

Kedudukan Menteri-menteri tersebut, adalah selaku Pengguna Anggaran (PA) sebagaimana diatur dalam Pasal 4 ayat (1) UU No. 1 Tahun 2004, bahwa Menteri/pimpinan lembaga adalah PA/Pengguna Barang bagi kementerian negara/lembaga yang dipimpinnya. Sedangkan PA untuk Pemerintahan Daerah dan pada tingkat Kepala Satuan Kerja Perangkat Daerah diatur dalam Pasal 5 ayat (1) dan Pasal 6 ayat (1) UU No. 1 Tahun 2004.

Selanjutnya mengenai pengertian PA dalam Pasal 1 Angka 5 Peraturan Presiden No. 54 Tahun 2010 jo Peraturan Presiden No. 70 Tahun 2012, tentang Pengadaan Barang/Jasa Pemerintah menegaskan bahwa PA sebagai Pejabat pemegang kewenangan penggunaan anggaran Kementerian/Lembaga/Satuan Kerja Perangkat Daerah atau Pejabat yang disamakan pada institusi lain Pengguna APBN/ APBD.

Salah satu kewenangan dari PA, yaitu mengangkat Kuasa PA (KPA) dan dalam Pasal 1 Angka 6 Peraturan Presiden No. 54 Tahun 2010 jo Peraturan Presiden No. 70 Tahun 2012, ditegaskan bahwa KPA sebagai pejabat yang ditetapkan oleh PA untuk menggunakan APBN atau ditetapkan oleh Kepala Daerah untuk menggunakan APBD. Namun demikian, dalam UU No. 1 Tahun 2004 jo Peraturan Presiden No. 54 Tahun 2010 jo Peraturan Presiden No. 70 Tahun 2012, dan Penjelasannya tidak mengatur tentang siapa yang dapat menjadi KPA. Adapun yang diatur hanya mengenai kedudukan KPA sebagaimana pada Pasal 10 Peraturan Presiden No. 54 Tahun 2010 jo Peraturan Presiden No. 70 tahun 2012, bahwa KPA merupakan pejabat yang ditetapkan atas usul PA dan memiliki kewenangan sesuai pelimpahan oleh PA. Dengan demikian, PA dapat saja melimpahkan wewenangnya dengan memberi kuasa kepada pejabat siapa saja, yang kemudian ditetapkan sebagai KPA dengan pertimbangan tertentu.

Dalam praktek penetapan sebagai KPA khusus untuk Kepala Unit Kerja pada SKPD yang akan ditetapkan sebagai KPA oleh Kepala Daerah atas usulan PA, adalah Kepala SKPD dengan mengacu pada Pasal 11 ayat (2) Peraturan Pemerintah No. 58 Tahun 2005, tentang Pengelolaan Keuangan Daerah dan Penjelasan Pasal 5 UU No. 1 Tahun 2004. Berdasarkan ketentuan ini, maka KPA bukanlah merupakan sebuah jabatan, baik secara struktural maupun fungsional, sehingga pertimbangan dalam pemilihan aparatur yang ditetapkan sebagai KPA tidak terikat, apakah KPA harus pejabat struktural ataupun pejabat fungsional. Dengan demikian, Kedudukan KPA harus dipandang sebagai aparatur atau siapapun yang di usulkan oleh PA dalam menjalankan kuasa, sehingga kewenangan KPA terbatas pada pelimpahan kewenangan yang diberikan, karena itu ketika KPA ditetapkan dalam pengadaan barang/jasa, maka 
kewenangannya pun sesuai dengan kewenangan PA sebagaimana yang diatur dalam Peraturan Presiden No. 54 Tahun 2010 jo Peraturan Presiden No. 70 Tahun 2012.

Kedudukan PA sebagai pemberi kuasa kepada KPA dalam praktek oleh Jaksa Penuntut Umum (JPU) sering diposisikan sebagai tersangka dalam perkara Tindak Pidana Korupsi (TPK), dan yang kemudian dijerat dengan Pasal 2 dan Pasal 3 UU Pemberantasan Tindak Pidana Korupsi. Pada hal kedudukan PA ini, selaku pihak pemberi kuasa dan sekaligus pemberi pelimpahan kewenangannya, menurut hukum seharusnya hanya dapat dijadikan sebagai saksi. Dengan fakta empirik ini, menjadi menarik untuk dikaji secara mendalam, terutama berkenaan dengan tanggung jawab pengguna anggaran dalam tindak pidana korupsi.

\section{B. ANALISIS DAN PEMBAHASAN}

\section{Pengguna Anggaran (PA) sebagai Tersangka/Terdakwa Dalam Perkara Korupsi}

Analisis terhadap PA dalam dugaan tindak pidana korupsi dilakukan terhadap perkara yang telah mempunyai kekuatan hukum mengikat (inkracht van gewijsde), yakni Perkara Register Nomor 18/Pid.Sus/2012/PN.Pl, yang melibatkan seorang Pejabat Kuasa Pengguna Anggaran (KPA) pada Biro Perlengkapan Umum dan Aset Sekretariat Daerah Provinsi Sulawesi Tengah Tahun Anggaran 2010 berdasarkan Surat Keputusan Gubernur Sulawesi Tengah Nomor: 954/126.7/RO.KEU-G.ST/2010 selaku Terdakwa, dan Perkara Register Nomor 117/Pid.B/2011/PN.Dgl yang melibatkan seorang Pj Bupati Kabupaten Sigi tahun 2010 yang diangkat berdasarkan SK Menteri Dalam Negeri Nomor 131.72-21 tahun 2010 tertanggal 15 Januari 2010 selaku Terdakwa.

Dalam Perkara Register Nomor 18/Pid.Sus/2012/PN.Pl tersebut, berdasarkan uraian dakwaan JPU, menunjukkan bahwa terhadap perbuatan melawan hukum yang dilakukan oleh Terdakwa, bersama-sama dengan saksi-saksi lainnya, bertentangan dengan ketentuan:

a. Keputusan Presiden Nomor 80 Tahun 2003 dengan segala perubahannya Pasal 5 huruf f dan g, disebutkan bahwa: "Pengguna Anggaran/Jasa, Penyedia Barang/ Jasa dan Para Pihak yang terkait dalam pelaksanaan pengadaan barang/jasa harus mematuhi etika yaitu huruf $\mathrm{f}$ : Menghindari dan mencegah terjadinya pemborosan dan kebocoran keuangan negara dalam pengadaan barang/jasa, dan huruf g: menghindari dan mencegah penyalahgunaan wewenang dan/atau kolusi dengan tujuan untuk keuntungan pribadi, golongan atau pihak lain yang secara langsung atau tidak langsung merugikan negara";

b. Penjelasan Pasal 33 ayat (2) Keputusan Presiden Republik Indonesia Nomor 80 Tahun 2003 menyatakan bahwa khusus untuk pekerjaan konstruksi, pembayaran hanya dapat dilakukan senilai pekerjaan yang telah terpasang, tidak termasuk bahan-bahan, alatalat yang ada di lapangan;

c. Pasal 18 ayat (3) UU No. 1 Tahun 2004, menyatakan bahwa Pejabat yang menandatangani dan atau mengesahkan dokumen yang bertentangan dengan surat yang menjadi dasar pengeluaran beban APBN/APBD bertanggungjawab atas 
kebenaran materiil dan akibat yang timbul dari penggunaan surat bukti dimaksud

d. Pasal 61 ayat (1) Peraturan Pemerintah Nomor 58 Tahun 2005 tentang Pengelolaan Keuangan Daerah, menyebutkan bahwa setiap pengeluaran harus didukung oleh bukti yang lengkap dan sah mengenai hak yang diperoleh oleh pihak yang menagih;

e. Pasal 132 ayat (1) Peraturan Menteri Dalam Negeri Nomor 13 Tahun 2006 tentang Pedoman Pengelolaan Keuangan Daerah, menyatakan bahwa setiap pengeluaran belanja atas beban APBD harus didukung dengan bukti yang lengkap dan sah dan ayat (2) menyatakan bahwa bukti sebagaimana dimaksud pada ayat (1) harus mendapat pengesahan oleh pejabat yang berwenang dan bertanggung jawab atas kebenaran materiil yang timbul dari penggunaan bukti dimaksud;

Akibat perbuatan Terdakwa bersama-sama dengan saksi lain mengakibatkan kerugian negara/daerah cq. Pemerintah Daerah Provinsi Sulawesi Tengah sebesar Rp. 424.275.000,- (empat ratus dua puluh empat juta dua ratus tujuh puluh lima ribu Rupiah), atau sekitar jumlah itu sebagaimana tertuang Laporan Hasil Perhitungan Kerugian atas Penyimpangan Pembangunan Gedung Wanita Provinsi Sulawesi Tengah Tahun Anggaran 2010 yang ditanda tangani oleh Plh. Kepala BPKP Perwakilan Sulawesi Tengah Nomor: SR-592/PW19/5/2012 tanggal 2 Maret 2012;

Selanjutnya, dalam Perkara Register Nomor 117/Pid.B/2011/ PN.Dgl, berdasarkan uraian dakwaan JPU menunjukkan bahwa perbuatan terdakwa bersama dengan Kepala Dinas PPKAD Kabupaten Sigi yang menyetujui permohonan pembayaran dari KPU Kabupaten Donggala, yang tidak ada laporan pertanggungjawaban keuangan dalam setiap tahap pencairan, bertentangan dengan :

a. Permendagri No. 13 Tahun 2006 yang telah diubah dengan Permendagri No. 59 Tahun 2007 tentang Pedoman Pengelolaan Keuangan Daerah Pasal 216 ayat (5) yang mensyaratkan kelengkapan dokumen SPM-LS untuk penerbitan SP2D mencakup :

- Surat pernyataan tanggungjawab pengguna anggaran/ kuasa pengguna anggaran, dan

- Bukti-bukti pengeluaran yang sah dan lengkap adalah yang sesuai dengan kelengkapan persyaratan yang diatur dalam peraturan perundangundangan.

Pasal 216 ayat (7) yang menegaskan jika SPM dinyatakan tidak lengkap dan/ atau tidak sah dan/ atau pengeluaran tersebut melampaui pagu anggaran, kuasa BUD menolak menerbitkan SP2D.

b. Naskah Perjanjian Hibah antara Pemerintah Kab. Sigi dan Komisi Pemilihan Umum (KPU) Kab. Donggala Nomor : 279/0117/Setda/2010 dan Nomor : 279/71/KPU/2010, Pasal 10 yang mengatur bahwa penyaluran bantuan hibah kepada pihak kedua yang karena ketentuan melalui mekanisme sesuai tahapan, penyaluran berikutnya dapat diberikan setelah pihak kedua selaku penerima hibah menyampaikan laporan pertanggungjawaban penggunaan bantuan hibah tahapan sebelumnya.

Atas perbuatan terdakwa bersama dengan Kepala Dinas PPKAD Kabupaten Sigi yang menyetujui untuk dibayarkan tanpa melakukan penelitian secara cermat dan seksama terhadap kelengkapan persyaratan pencairan dana dan evaluasi terhadap 
permohonan pembayaran yang diajukan oleh pihak KPU Kab. Donggala menyebabkan penggunaan dan peruntukkan dananya menjadi tidak jelas, hingga akhirnya pada sekira bulan September 2010 dana kegiatan Pemilihan Umum Kepala Daerah dan Wakil Kepala Daerah Kab. Sigi periode tahun 2010-2015 Kabupaten Sigi tahun 2010 sebesar Rp 10.314.133.970,- (sepuluh milyar tiga ratus empat belas juta seratus tiga puluh tiga ribu sembilan ratus tujuh puluh rupiah) habis tanpa ada pertangungjawaban penggunaan dan peruntukkan dananya, padahal tahapan kegiatan Pemilihan Umum Kepala Daerah dan Wakil Kepala Daerah Kab. Sigi periode tahun 2010-2015 belum selesai seluruhnya (masih dalam tahap Pendistribusian Surat Suara).

Dikarenakan dana sudah habis sedangkan kegiatan Pemilihan Umum Kepala Daerah dan Wakil Kepala Daerah Kab. Sigi periode tahun 2010-2015 Kab. Sigi tahun 2010 belum selesai, maka KPU Kab. Donggala mengajukan permohonan tambahan dana kepada pihak Pemerintah Daerah Kab. Sigi sebesar Rp 2.226.043.000,- (dua milyar dua ratus dua puluh enam juta empat puluh tiga ribu rupiah) dengan surat permohonan permintaan tambahan dana Pemilihan Umum Kepala Daerah dan Wakil Kepala Daerah Kab. Sigi periode tahun 2010-2015 Nomor: 270/217/KPU /X/2010 tanggal 2 September 2010 yang ditandatangani oleh Ketua KPU Kab. Donggala.

Kemudian pihak Pemerintah Kab. Sigi yang dalam hal ini diwakili Kadis DPPKAD Kab. Sigi dan terdakwa (Pj. Bupati Kab. Sigi) tanpa adanya laporan pertanggungjawaban penggunaan dana penyelengaraan Pemilihan Umum Kepala Daerah dan Wakil Kepala Daerah Kab. Sigi periode tahun 2010-2015 senilai Rp 10.314.133.970,- (sepuluh milyar tiga ratus empat belas juta seratus tiga puluh tiga ribu sembilan ratus tujuh puluh rupiah), tanpa melakukan verifikasi dan evaluasi serta tanpa sepengetahuan DPRD Kab. Sigi sebagaimana yang disyaratkan dalam Permendagri No. 13 Tahun 2006 yang telah dirubah dengan Permendagri No. 59 Tahun 2007 tentang Pedoman Pengelolaan Keuangan Daerah Pasal 216 ayat (5) huruf a dan b jo Pasal 216 ayat (7) dan tanpa memberitahukan kepada pihak DPRD Kab. Sigi untuk mendapatkan keabsahan penggunaan anggaran belanja daerah sebagaimana yang disyaratkan Pasal 30 ayat (1) dan ayat (3) Permendagri No. 44 tahun 2007 dan perubahannya Permendagri No. 57 Tahun 2009 tentang Pedoman Pengelolaan Belanja Pemilihan Umum Kepala Daerah dan Wakil Kepala Daerah.

Terdakwa bersama-sama dengan Kepala Dinas PPKAD Kab. Sigi telah menyetujui penambahan dana tersebut yang kemudian dituangkan kembali dalam Naskah Perjanjian Hibah Tambahan Belanja KPU Kepala Daerah dan Wakil Kepala Daerah Kab. Sigi Tahun 2010 pada Putaran Pertama No: 279/0589.a/B-Sigi/2010 dan No: 279/190/KPU-DGL/2010 tanggal 7 September 2010 antara pihak Pemerintah Kab. Sigi yang diwakili oleh terdakwa (Pj. Bupati Sigi) dan pihak KPUD Kab. Donggala yang diwakili oleh Ketua KPUD Kab. Donggala dan telah dibayarkan. Usulan penambahan dana senilai $\mathrm{Rp} 2.225 .000 .000$,- (dua milyar dua ratus dua puluh lima juta rupiah) yang diusulkan kepada pihak Pemerintah Kab. Sigi sebetulnya adalah kegiatan yang sudah dianggarkan sebelumnya, sehingga terdapat beberapa kegiatan yang fiktif. 
Terdakwa selaku Pj. Bupati Kab. Sigi tahun 2010 semestinya tidak menyetujui permohonan penambahan dana oleh KPUD Kab. Donggala tersebut, apabila laporan pertanggungjawaban penggunaan keuangan sebelumnya tidak ada dalam surat permohonan tersebut, sehingga akibat dari tindakan terdakwa tersebut saksi pertama telah menikmati uang sebesar Rp 241.000.000,- (dua ratus empat puluh juta rupiah) dan saksi kedua sebesar Rp 882.755.000,- (delapan ratus delapan puluh dua juta tujuh ratus lima puluh lima ribu rupiah) yang berasal dari anggaran dana Pemilihan Umum Kepala Daerah dan Wakil Kepala Daerah Kab. Sigi Tahun 2010.

Berdasarkan Perhitungan Kerugian Keuangan Negara atas Kasus tersebut oleh Tim Penyidik Kejaksaan Negeri Donggala dengan perhitungan yang dihitung berdasarkan LPJ dari bulan Maret sampai dengan Juni 2010 dan rekapitulasi Surat Pertanggungjawaban (SPJ) dari bulan Juli sampai dengan Oktober 2010. Penarikan Dana dari Rekening KPU Kab. Donggala sebesar Rp. 6.072.528.773,- diperoleh dari LPJ bulan Maret sampai dengan Juni 2010, sebesar Rp. 3.280.897.000,- ditambah rekapitulasi SPJ Juni s/d Oktober 2010, sebesar Rp. 2.791.631.773.

Akibat yang perbuatan Terdakwa bersama-sama dengan saksi lain mengakibatkan kerugian negara dengan penyimpangan keuangan yang terjadi seperti tersebut di atas, mengakibatkan kerugian keuangan negara sebesar Rp. 7.128.431.227,- (tujuh milyar seratus dua puluh delapan juta empat ratus tiga puluh satu ribu dua ratus dua puluh tujuh rupiah). Jumlah tersebut, merupakan selisih antara penarikan/pengambilan dana dari rekening, KPUD Kab. Donggala dengan pertanggungjawaban penggunaannya.

Dalam hukum pidana, parameter tanggung jawab pidana adalah kesalahan. Tidak dipidana jika tidak ada kesalahan (Geen Straf Zonder Schuld). Dalam doktrin, untuk adanya kesalahan harus melakukan perbuatan melawan hukum, mampu bertanggung jawab, perbuatan itu dilakukan dengan sengaja atau kealpaan, dan tidak ada alasan pemaaf ${ }^{1}$.

Dari dua putusan tersebut di atas, PA didudukkan sebagai Tersangka/Terdakwa dalam perkara korupsi, berdasarkan atas:

a. Perbuatan tersebut melawan hukum atau perbuatan pidana

Tindakan melawan hukum sudah jelas diatur di dalam Pasal 2 ayat (1) UU No. 31 Tahun 1999 jo UU No. 20 Tahun 2001, yang berbunyi setiap orang dengan cara melawan hukum melakukan perbuatan memperkaya diri sendiri atau orang lain atau suatu korporasi yang dapat merugikan keuangan negara.

Mengenai hal ini, Mahkamah Konstitusi (MK) memberikan putusan tentang perbuatan melawan hukum, yaitu Putusan MK No. 003/ PUU-IV/2006, konsep melawan hukum materil (materiel wederrechtelijk), yang merujuk kepada hukum tidak tertulis dalam ukuran kepatutan, kehati-hatian dan kecermatan yang hidup dalam masyarakat, sebagai suatu norma keadilan adalah merupakan ukuran yang

${ }^{1}$ Amiruddin, Korupsi Dalam Pengadaan Barang Dan Jasa, Yogyakarta, Genta. Publising, 2010,hal, 93- 
tidak pasti, dan berbeda-beda dari suatu masyarakat tertentu ke lingkungan masyarakat lainya, sehingga apa yang melawan hukum di satu tempat, mungkin di tempat lain diterima dan diakui sebagai suatu yang sah dan tidak melawan hukum, menurut ukuran masyarakat setempat.

Sifat Melawan hukum dalam TPK, memiliki pertanggungjawaban pribadi, karena ini adalah murni tindak pidana dan bukan merupakan kesalahan jabatan yang penyelesaiannya, adalah gugatan terhadap tindakan yang harus diselesaikan melalui PTUN, melainkan perbuatan melawan hukum, adalah salah satu karakter kesalahan pribadi yang memiliki pertanggungjawaban pidana.

b. Menggunakan wewenang untuk tujuan lain dari yang menjadi tujuan wewenang atau melakukan penyalahgunaan wewenang

Penyalahgunaan wewenang diatur di dalam Pasal 3, berbunyi setiap orang yang dengan tujuan menguntungkan diri sendiri dengan orang lain atau korporasi, menyalahgunakan kewenangan dan kesempatan atau sarana yang ada padanya karena jabatan, dan kedudukan yang dapat merugikan keuangan Negara atau perekonomian Negara.

Penyalahgunaan wewenang merupakan jenis tindak pidana yang hanya dapat dilakukan oleh pejabat, karena adanya wewenang harus disertai dengan adanya jabatan. Menurut penulis, penyalahgunaan wewenang adalah salah satu karakter dari kesalahan pribadi, karena bentuk dari pertanggungjawaban penyalahgunaan wewenang adalah pertanggungjawaban pidana.

c. Kelalaian atau pengabaian kewajiban

Kelalaian terhadap kewajiban adalah tindakan pejabat yang tidak melaksanakan kewajiban atau tidak melaksanakan tugas yang dibebankan oleh Negara kepada pejabat tersebut.

Kesalahan jabatan, adalah perbuatan tersebut sudah bertentangan dengan legalitas tindakan pejabat dalam hal ini pejabat yang bertumpu pada wewenang, prosedur dan subtansi. Setiap tindakan pejabat harus bertumpu kepada wewenang, dan sumber wewenang adalah atribusi, delegasi dan mandat.

Kesalahan jabatan mempunyai karakter/ciri sebagai berikut:

a. Tindakan sewenang-wenang adalah tindakan yang diluar wewenang atau tindakan yang bukan wewenang dari pejabat (PA/KPA) tersebut, ada tiga macam tindakan sewenang-wenang, yaitu:

1. Onbevoegheid ratione materi" berarti pejabat tersebut tidak memiliki dasar wewenang untuk melakukan tindakan tersebut.

2. Onbevoeghed ratione loci, pejabat tersebut melakukan tindakan yang bukan pada tempat kewenangan dari pejabat tersebut.

3. Onbevoeghed ratione temporis, pejabat tersebut melakukan tindakan pada waktu yang sudah habis, atau waktu tersebut sudah membuat pejabat tidak memiliki wewenang lagi." 
Karakter tindakan sewenang-wenang di atas, selama kesalahan tersebut masih dalam ranah administrasi, dan bukan menjadi perbuatan melawan hukum, masih dikatagorikan sebagai kesalahan jabatan menurut hukum administrasi, tetapi apabila ada sifat melawan hukum, maka kesalahan tersebut menjadi ruang lingkup hukum pidana.

b. Kesalahan prosedur/administrasi

Kesalahan prosedur dalam hal ini merupakan kesalahan yang dimaksudkan ke dalam ranah hukum administrasi, yang pertanggungjawaban hukumnya adalah bersifat administrasi dan tidak memiliki sifat melawan hukum sebagaimana yang dimaksudkan dalam hukum pidana. Dalam hubungannya dengan TPK yang ada dalam Pasal 2 UUPTPK, pelanggaran administrasi merupakan penyebab timbulnya sifat melawan hukum, apabila terdapat unsur sengaja (kehendak dan keinsafan) untuk menguntungkan diri dengan menyalahguna-kan kekuasaan jabatan, yang karena itu merugikan perekonomian atau keuangan Negara, perbuatan administrasi yang memenuhi syarat-syarat yang demikian itu, membentuk pertanggungjawaban pidana atau menjadi yang merugikan keuangan Negara, maka yang terjadi adalah kesalahan prosedur/administrasi, dan tidak ada sifat melawan hukumnya, melainkan perbuatan ini semata-mata kesalahan prosedur saja yang memiliki pertanggungjawaban hukum administrasi.

Kesalahan prosedur/administrasi dibedakan menjadi tiga macam sebagai berikut ${ }^{2}$ :

1. Kesalahan administrasi murni. Terjadi apabila melakukan kesalahan administrasi karena khilaf (lupa), baik karena ketentuan prosedural/tatalaksana maupun akibatnya. Perbuatan khilaf ini tidak membawa kerugian apapun bagi kepentingan hukum Negara, dan pertanggungjawaban hukumnya adalah administrasi.

2. Si pembuat khilaf (culpoos) dalam melaksanan prosedur pekerjaan tertentu, yang dari pekerjaan ini menimbulkan kerugian Negara, misalnya nilai uang tertentu. Kasus semacam ini, masuk dalam perbuatan onrechtsmatige daad dalam hukum perdata (Pasal 1365 BW), pertanggungjawaban hukumya adalah ganti rugi.

3. Si pembuat sengaja mengelirukan pekerjaan administratif tertentu, namun tidak dapat membawa dampak kerugian dan kepentingan Negara, kesalahan seperti ini masih ditoleransi sebagai kesalahan administrasi, dan sanksi administrasi dapat dijatukan kepada si pembuat kesalahan ini.

Kesalahan administratif di atas, merupakan salah satu indikator kesalahan jabatan yang pertanggungjawaban hukumnya bersifat administratif.

${ }^{2}$ www.adamichazawi.blogspot.com Sifat melawan hukum tindak pidana korupsi, (diakses tgl 5 November 2016) 
c. Tindakan melanggar asas-asas umum pemerintahan yang baik (AUPB) yang dilakukan oleh pejabat

Seringkali dalam putusan pengadilan terdapat kekeliruan dalam memberikan putusan, salah satunya dalam hal memutuskan pelanggaran terhadap AUPB merupakan bentuk tindak pidana. Menurut penulis, melanggar asas bukan bentuk dari tanggung jawab pribadi atau tanggung jawab pidana, melainkan melanggar asas, adalah bentuk dari tindakan jabatan yang salah, yang seharusnya pertanggungjawaban hukumnya adalah tanggungjawab jabatan yang dapat digugat dalam Pengadilan Tata Usaha Negara (PTUN).

Karl Larenz, dalam Amiruddin ${ }^{3}$ menjelaskan asas hukum sebagai berikut:

Rechtsprinzipien sind leitende gedanken einer (moglichen oder bestebenden) rechtlichen Regulung, die selbst noch keine der 'Anwedung' fachige Reglnsind, aber in solche umgesetzt warden konnen". (Asas-asas hukum adalah gagasan yang membimbing dalam peraturan hukum yang mungkin ada atau sudah ada, yang dirinya sendiri yang bukan merupakan aturan yang dapat ditetapkan, tetapi yang dapat dirubah menjadi demikian)."

Asas hukum merupakan pikiran yang ada di belakang norma hukum, oleh sebab itu asas hukum jelas tidak sama dengan norma hukum atau aturan hukum, jadi apabila melakukan pelanggaran asas tidak dapat dipidana, karena pelanggarannya merupakan tindakan kesalahan jabatan yang pertanggungjawabannya adalah berbentuk pertanggung-jawaban jabatan.

Dengan merujuk kepada prinsip persamaan di depan hukum (equality before the law), bahwasanya siapapun baik itu dikalangan elit Pemerintah atau pejabat harus mempertanggungjawabkan kesalahannya, karena di dalam hukum pidana seseorang bertanggung jawab atas perbuatannya, apabila perbuatan tersebut memiliki kesalahan, sesuai dengan asas hukum pidana (green straf zonder schuld), tidak ada pidana tanpa kesalahan, dan kesalahan tersebut sudah diatur oleh UU, dan perbuatan tersebut dinyatakan salah dan memiliki sanksi.

\section{Tanggungjawab hukum atas Kuasa yang diberikan oleh Pengguna Anggaran (PA) kepada Pengguna Anggaran}

Pada Perkara Register Nomor 18/Pid.Sus/2012/PN.Pl, Majelis hakim yang memeriksa dan menyidangkan perkara tersebut memberikan pertimbangan mengenai tanggungjawab hukum PA, sebagai berikut:

1. Dalam setiap aktifitas, legalitas hukum yang digunakan sebagai acuan untuk menyatakan apakah seseorang berwenang atau tidak berwenang untuk melakukan suatu perbuatan hukum. Hal ini berkaitan erat dengan kekuatan mengikat dari seluruh pekerjaan itu, kepada orang-orang yang diberikan jabatan dan wewenang untuk melaksanakan kegiatan atau perbuatan hukum yang dimaksud. Dan yang

\footnotetext{
${ }^{3}$ Amiruddin, Korupsi Dalam Pengadaan Barang, Op.cit. hal. 138.
} 
dijadikan dasar yuridis bahwa kewenangan yang ada pada orang-orang yang diangkat adalah berdasarkan peraturan perundang-undangan, sementara itu kalau ditelusuri, BPK yang diperlengkapi dengan Tim Teknis diangkat berdasarkan peraturan perundang-undangan dan diberikan kewenangan yang diserahkan kepadanya untuk memeriksa pekerjaan-pekerjaan yang dananya bersumber dari ABPD maupun APBN. Sedangkan Tim Independen dari Fakultas Teknik Universitas Tadulako bekerja melakukan pemeriksaan atas hasil pekerjaan Pembangunan Gedung Wanita Tahap III berdasarkan surat tugas dari Rektor, sedangkan Rektor sendiri tidak punya kewenangan sebagaimana kewenangan yang dimiliki oleh BPK. Sehingga perbuatan Terdakwa tersebut tidak dapat dikatagorikan sebagai suatu perbuatan melawan hukum, sebab Terdakwa melaksanakan amanat perundang-undangan yang diberikan kepadanya selaku PA dalam pekerjaan Pembangun Gedung Wanita Tahap III, dimana dalam pekerjaan Pembangunan Gedung Wanita Tahap III tersebut telah dilakukan sesuai dengan prosedur atau tahapan sebagaimana yang telah ditentukan dalam Keputusan Presiden No. 80 Tahun 2003 tentang Pengadaan Barang dan Jasa Pemerintah. Secara dejure dan defacto banyak organ yang dipakai dalam pekerjaan Pengadaan Barang dan Jasa Pemerintah. Pertama harus dipahami prosedur pengadaan barang dan jasa yang dimulai dari tahapan pelelangan, siapa yang diberikan kewenangan sebagai Panitia lelang, kemudian dalam tahapan kontrak, siapa diberikan kewenangan tandatangan kontrak, dan pada tahapan pemeriksaan barang, siapa yang diberikan kewenangan untuk memeriksa barang, lalu siapa yang memiliki kewenangan selaku penerimaan barang. Takkala dipahami tahapan pengelolaan barang dan jasa atau pelaksanaan kegiatan ini maka kemudian diposisikan, dimana posisi Terdakwa? Bahwa posisi Terdakwa, dimana ada orang bertindak karena jabatan, ada perintah jabatan. Dan jabatan senantiasa memperlihatkan wewenang bebas atau wewenang terikat. Maka tatkala seorang pejabat berada dalam wewenang terikat, dimana semua prosedur telah dilakukan, sehingga tidak ada alasan bagi pejabat tersebut untuk mengatakan tidak bisa menandatangani laporan. Kalau Terdakwa berada dalam wewenang bebas, maka ada kesempatan untuk menilai, apakah yang akan dilakukan itu harus dilakukan atau masih bisa tidak dilakukan. Sehingga, dalam hal ini Majelis berpendapat bahwa Terdakwa sebagai pejabat dalam wewenang terikat. Selanjutnya, apakah sesuatu hal itu menjadi wewenang atau tidak menjadi wewenang, tentu ada dasar hukumnya. Terdapat Surat Keputusan Gubernur yang menunjuk Terdakwa, berarti dari sisi wewenang maka Terdakwa punya wewenang; Kedua, soal substansi, apa yang menjadi substansi dari kewenangan itu? Dalam Surat Keputusan Gubernur juga diuraikan apa kewenangan yang harus dilakukan oleh Terdakwa, berarti secara substansi juga merupakan kewenangan Terdakwa. Sekarang berbicara soal prosedur: Ada Konsultan Pengawas yang menyatakan sudah selesai 100\%, Ada Panitia Pemeriksa Barang katakan sudah selesai 100\%, ada Penerima Barang katakan sudah selesai $100 \%$, sehingga tidak ada alasan bagi Terdakwa selaku PA untuk tidak menandatangani dokumen tatkala semua dokumen-dokumen yang dari bawah itu sudah dilakukan dan dinyatakan lengkap. Panitia Pemeriksa barang sudah menandatangani berita acara pemeriksaan yang menyatakan sudah $100 \%$, 
kemudian penerima barang menandatangani dan menyatakan sudah $100 \%$ sesuai bestek, dengan demikian tidak ada kewenangan bagi Terdakwa untuk mengatakan tidak mau bertanda tangan dokumen tersebut, mengingat secara prosedur sudah dilakukan dari bawah dan itu sah. Mengenai penandatangan terakhir adalah Terdakwa, itu artinya bahwa kalau itu palsu dari bawah, maka semua orang-orang yang bertandatangan tentang ketidakbenaran dokumen-dokumen itu seharusnya diseret semua ke meja hijau ini, termasuk Bendahara yang mencairkan uang, karena dengan dokumen yang tidak benar, kenapa kemudian seorang Bendahara keuangan berani mencairkan anggaran berdasarkan dokumen yang tidak benar. Dengan demikian secara substansi semua dokumen itu tidak ada yang tidak benar, karena di dalam hukum administrasi ada satu asas yang fundamental yaitu asas praduga "rechtmatig" artinya setiap tindakan pejabat Tata Usaha Negara selalu dianggap sah sampai dibuktikan sebaliknya oleh Pengadilan. Oleh karenanya apa yang dilakukan Terdakwa sampai hari ini sah, sebelum diuji kebenarannya di Pengadilan. Dan tidak ada alasan bagi Terdakwa untuk menolak menandatangani dokumen tersebut, maka demi hukum seorang pejabat yang memiliki kewenangan mengikat harus melakukan tindakan itu, justru kalau tidak melaksanakan kewenangan itu maka berarti ada penyalahgunaan wewenang di dalamnya.

2. Selanjutnya, dalam menentukan besarnya kerugian keuangan negara dalam pelaksanaan pekerjaan Pembangunan Gedung Wanita Tahap III ini mempedomani dan merujuk kepada hasil perhitungan Badan Pemeriksa Keuangan Perwakilan Sulawesi Tengah yakni telah terjadi kerugian keuangan negara sebesar Rp. 76.342.837,- (tujuh puluh enam juta tiga ratus empat puluh dua ribu delapan ratus tiga puluh tujuh Rupiah). Hal ini didasarkan kepada alasan selain karena hasil temuan Tim Ahli Independen dari Fakultas Teknik Universitas Tadulako didasarkan kepada pemeriksaan yang dilakukan 8 (delapan) atau 9 (sembilan) bulan setelah selesainya pelaksanaan pekerjaan Pembangunan Gedung Wanita Tahap III juga karena pada saat dilakukan pemeriksaan dalam persidangan maupun pemeriksaan setempat Ahli yang diajukan oleh Penuntut Umum tidak bisa menjelaskan kepada Majelis tentang beberapa item-item pekerjaan dimana hasil perhitungan atas item-item pekerjaan yang tidak bisa dijelaskan itu hanya didasarkan kepada asumsi-asumsi belaka dari Ahli, untuk itu Majelis mengenyampingkan hasil temuan dari Tim Ahli Independen tersebut.

3. Berdasarkan uraian pertimbangan sebagaimana yang telah dipaparkan di atas, maka Majelis berpendapat bahwa perbuatan Terdakwa yang telah menandatangani dokumen-dokumen yang isinya menyatakan bahwa bobot pelaksanaan pekerjaan Pembangunan Gedung Wanita Tahap III telah mencapai 100\% bukanlah atau dapat pula dikategorikan sebagai perbuatan melawan hukum atau perbuatan tidak patut sebagaimana dimaksud dalam ketentuan Pasal 2 ayat (1) UU No. 31 Tahun 1999 yang telah diubah dan ditambah dengan UU No. 20 Tahun 2001 tentang Perubahan atas UU No. 31 Tahun 1999 tentang PTPK, dengan demikian unsurunsurnya tidak terpenuhi.

Selanjutnya, pada Perkara Register Nomor 117/Pid.B/2011/ PN.Dgl, Majelis Hakim yang memeriksa dan menyidangkan perkara tersebut memberikan pertimbangan mengenai tanggungjawab hukum PA, sebagai berikut: 
1. Berdasarkan fakta yang terungkap di persidangan dikaitkan dengan surat dakwaan, maka yang dimaksud setiap orang adalah orang perseorangan yakni Terdakwa yang pada saat tempus delicti dan locus delicti dalam keadaan menjabat sebagai Pejabat Sementara (Pj) Bupati Sigi, dengan identitas sebagaimana tersebut dalam surat dakwaan. Sehingga telah jelas yang dimaksud setiap orang adalah menunjuk pada Terdakwa dengan demikian maka unsur "setiap orang" telah terpenuhi oleh diri Terdakwa;

2. Bentuk-bentuk penyertaan (deelneming) tersebut adalah, bentuk pertama yakni melakukan (plegen) menunjuk pada dilakukannya perbuatan itu dengan sumbangan penyertaan lain-lain orang, bentuk kedua menyuruhlakukan (doenplegen) terjadi sebelum dilakukannya perbuatan dengan menyuruhlakukan perbuatan dengan perantaraan orang lain atau dengan kata lain seseorang mempunyai kehendak untuk melaksanakan suatu tindak pidana, namun orang yang berniat tersebut tidak mau melakukannya sendiri, tetapi mempergunakan orang lain yang disuruh melakukannya, dan bentuk ketiga adalah turut serta melakukan (medeplegen) menunjuk pada adanya kerjasama yang erat di antara peserta pada waktu melakukan tindak pidana, untuk itu perbuatan masing-masing peserta tidaklah dilihat satu-persatu secara berdiri sendiri, tetapi perbuatan masing-masing peserta harus dinilai dalam hubungannya dan sebagai kesatuan dengan perbuatanperbuatan peserta lainnya;

3. Fakta yang terungkap di persidangan, bahwa perbuatan Terdakwa yang telah menyetujui pencairan dana hibah Pemilukada Sigi 2010 dalam tiga tahap, sehingga berjumlah Rp. 10.314.133.970,- (Sepuluh milyar, tiga ratus empat belas juta seratus tiga puluh tiga ribu Sembilan ratus tujuh puluh rupiah) dari tambahan dana hibah hingga sejumlah Rp 2.256.043.000,- (dua milyar dua ratus lima puluh enam juta empat puluh tiga ribu rupiah), sehingga kesemuanya berjumlah $\mathrm{Rp}$. 13.200.960.000,-, untuk kepentingan Pemilukada Sigi 2010, sehingga Kepala DPKAD atas persetujuan Terdakwa tersebut lalu memindahbukukan dana tersebut dari kas Daerah Sigi ke dalam rekening KPU Donggala, sehingga pada akhirnya KPU mempertanggungjawabkan penggunaan dana tersebut sejumlah Rp 6.072.528.773, sedangkan sisanya sejumlah Rp. 7.128.431.227,- tidak ada pertanggungjawabannya. Dari peristiwa tersebut telah terjadi bentuk berupa "turut serta melakukan" karena menunjuk adanya kerjasama yang erat dari peserta tersebut. Sehingga dengan demikian maka unsur "melakukan, menyuruhlakukan, atau turut serta melakukan", dalam hal ini kapasitasnya adalah turut serta melakukan telah terpenuhi menurut hukum dalam perbuatan Terdakwa;

4. Dalam konteks cakupan "secara melawan hukum" dalam unsur ini adalah bahwa terdakwa dalam melakukan perbuatan memperkaya diri sendiri atau orang lain atau korporasi adalah dengan cara yang bersifat melawan hukum. Mengenai fungsi unsur melawan hukum sendiri dalam konstruksi delik, dalam sejarahnya ditemukan dalam penjelasan umum Pasal 1 sub a UU 3/1971, bahwa hal ini tidak menjadikan perbuatan melawan hukum sebagai suatu perbuatan yang dapat dihukum, melainkan melawan hukum ini adalah "sarana" untuk melakukan perbuatan yang dapat dihukum, yaitu memperkaya diri sendiri atau orang lain atau korporasi. Dan perubahan orientasi fungsi melawan hukum serta perbuatan yang dapat dihukum menjadi sebagai sarana untuk melakukan perbuatan yang dapat dihukum, bisa dilihat dari penjelasan umum UU 3/1971, bahwa pada saat 
perumusan TPK sebagaimana dalam UU Nomor: 24/PRP/1960, banyak perbuatanperbuatan yang merugikan perekonomian dan keuangan Negara yang menurut perasaan keadilan masyarakat harus dituntut dan dipidana, tidak dapat dipidana karena perumusan tersebut mensyaratkan bagi TPK, adanya suatu kejahatan atau pelanggaran yang dilakukan oleh pelaku.

5. Dalam kenyataan banyak perbuatan yang merugikan keuangan dan perekonomian Negara tidak selamanya didahului dengan suatu kejahatan dalam masyarakat, maka perbuatan tersebut dapat dipidana, dimana cakupan pengertian ini menurut kepustakaan hukum pidana merupakan ajaran sifat melawan hukum materiil dalam fungsinya yang positif, atau dalam terminologi kriminologi diistilahkan sebagai gejala kriminalisasi. Khusus mengenai pengertian "secara melawan hukum" yang diberi cakupan perbuatan melawan hukum dalam arti materiel dalam fungsinya yang positif sebagaimana dalam Penjelasan Pasal 2 ayat (1) UU 31/1999 sebagaimana diubah dengan UU 20/2001, sesuai dengan Putusan Mahkamah Konstitusi Nomor 003/PUUIV/2006 tanggal 24 Juli 2006 dinyatakan tidak mempunyai kekuatan hukum mengikat karena bertentangan dengan UUD 1945. Di samping itu dalam kepustakaan hukum pidana dikenal pula ajaran sifat melawan hukum materiil dalam fungsinya yang negatif, yaitu suatu perbuatan, meskipun menurut peraturan perundang-undangan merupakan perbuatan yang bersifat melawan hukum, tetapi jika menurut penilaian masyarakat perbuatan tersebut tidak bersifat melawan hukum perbuatan dimaksud adalah perbuatan yang tidak bersifat melawan hukum, atau dalam terminologi kriminologi diistilahkan sebagai gejala dekriminalisasi. Penerapan ajaran ini sebagaimana tampak dalam Putusan Mahkamah Agung RI tanggal 08 Januari 1966 Nomor 42 K/Kr/1965 dengan terdakwa MACHROES EFFENDI, yang perbuatannya memenuhi unsur-unsur Pasal 372 jo. 52 jo. 64 ayat (1) KUHP, dan Putusan Mahkamah Agung RI tanggal 30 Maret 1977 Nomor 81/K/Kr/1973 dengan terdakwa Ir. Mach Otjo Danaatmadja bin Danaatmadja yang perbuatannya memenuhi unsur Pasal 415 jo. 64 KUHP jo. Pasal 1 sub c UU Nomor 24/PRP/1060, meskipun kedua terdakwa tersebut perbuatannya memenuhi ketentuan pidana dalam surat dakwaan, tetapi terdakwa dinyatakan lepas dari segala tuntutan hukum, karena terdapat faktor yang menghapuskan sifat melawan hukum dari perbuatan terdakwa, yakni berupa: (a) kepentingan umum yang dikerjakan atau dilayani oleh terdakwa; (b) Kepentingan pribadi yang tidak diperoleh terdakwa, dan (c) Kerugian yang tidak diderita oleh Negara atau masyarakat (dikutip dari R. Wiyono, Pemberantasan Undang Undang Tindak Pidana Korupsi, Sinar Grafika, Jakarta, 2006, hlm. 30). Dalam hal ini Majelis berpendirian bahwa penerapan "ajaran sifat melawan hukum materiil dalam 
fungsinya yang negatif harus benar-benar dilihat secara kasuistik, seksama dan perlu ketelitian dalam mempertimbangkan hukumnya, apakah ada situasi darurat atau mendesak sehingga pelaku melakukan perbuatan demikian, dan dari perbuatan tersebut apakah ada atau tidak ada kepentingan hukum yang dilanggar, atau apakah ada perkembangan ke arah pergeseran hukum di masyarakat, pencermatan ini untuk menghindari penerapan umum secara serampangan yang dapat dijadikan pelaku sebagai alat pembenaran atas perbuatan koruptifnya sehingga justru dapat mendorong pada berkembangnya TPK di masyarakat. Jika dikaitkan dalam kasus ini, berdasarkan fakta hukum yang terungkap di persidangan, bahwa Terdakwa terturut-turut telah menyetujui pemindahbukuan dari Kas Daerah ke rekening Bendahara KPU, dana hibah tahap 2 dan 3, serta menyetujui tambahan dana hibah, sehingga keseluruhannya berjumlah Rp. 13.200.960.000,-,; Dan persetujuan yang diberikan Terdakwa selaku Pj Bupati tersebut dengan berdasarkan pada naskah hibah yang telah disepakati bersama antara Terdakwa selaku Pj Bupati dengan Ketua KPU, dimana dinyatakan dana tersebut ditujukan untuk pelaksanaan Pemilukada Sigi 2010. Serta dikaitkan dengan suksesnya Pemilukada Sigi 2010 ini hingga terpilih Bupati dan Wakil Bupati definitif memang menjadi beban tanggungjawab Terdakwa selaku Pj. Bupati. Sehingga persetujuan Terdakwa dalam pencairan tahapan dana hibah Pemilukada Sigi 2010 tersebut dijadikan terdakwa sebagai sarana untuk memperkaya diri diri atau orang lain atau korporasi secara tidak sah? Jika menelisik dana yang dikeluarkan Bendahara Pemilukada, sebagaimana dalam barang bukti surat nomor 26-29 dan nomor 35, yang diserahkan Bendahara kepada Ketua KPU Donggala, berdasarkan fakta yang terungkap di persidangan, dari keterangan saksi-saksi, ternyata tidak ada dana yang diserahkan Ketua KPU Donggala kepada Terdakwa. Dengan demikian tidak terbukti Terdakwa menjadikan persetujuannya tersebut sebagai sarana untuk memperkaya diri sendiri secara tidak sah.

6. Dalam hal ada orang lain atau suatu korporasi yang memperoleh kekayaan yang tidak sah sebagai imbas dari persetujuan Terdakwa tersebut, sebagaimana tergambar dalam keterangan saksi-saksi dan keterangan terdakwa, hal ini adalah diluar dari maksud dan tujuan Terdakwa dalam memberikan persetujuan pencairan dan penambahan dana yang dimaksudkan untuk suksesnya Pemilukada Sigi, karena sebagaimana dalam naskah hibah, sebagaimana dalam tugas Terdakwa sebagai Pejabat Bupati di Kabupaten yang baru raja dimekarkan yang tugas utamanya adalah menyelenggarakan pernilukada untuk mendapatkan Bupati dan wakil Bupati definitif, sebagaimana dalam situasi psiko-sosiologis masyarakat kabupaten yang mendambakan terpilihnya Kepala Daerah, sebagaimana dalam situasi yang dituntut untuk bisa mengkalkukasi resiko pengambilan keputusan secara cepat dan tepat. Dengan demikian persetujuan terdakwa dalam mencairkan tahapan dana hibah dan persetujuan dalam penambahan dana hibah, adalah tidak sebagai sarana untuk memperkaya diri sendiri atau orang lain atau suatu korporasi. Dan untuk itu haruslah dinyatakan Terdakwa haruslah dibebaskan karena tidak terbukti secara sah dan meyakinkan. 
Berdasarkan uraian di atas, menunjukkan bahwa pertanggungjawaban hukum PA hanya sebatas :

a. Mempertanggungjawabkan amanat sesuai dengan perundang-undangan yang diberikan kepadanya selaku KPA, terkait itu maka apakah sesuai dengan prosedur atau tahapan sebagaimana yang telah ditentukan dalam Keputusan Presiden Nomor 80 Tahun 2003 tentang Pengadaan Barang dan Jasa Pemerintah.

b. Kewenangan terikat, dimana semua prosedur telah dilakukan, sehingga tidak ada alasan bagi pejabat tersebut untuk mengatakan tidak bisa menandatangani laporan. Jika KPA berada dalam wewenang bebas, maka ada kesempatan untuk menilai, apakah yang akan dilakukan itu harus dilakukan atau masih bisa tidak dilakukan.

c. Ketelitian dalam mempertimbangkan hukumnya, apakah ada situasi darurat atau mendesak, sehingga pelaku melakukan perbuatan demikian, dan dari perbuatan tersebut apakah ada atau tidak ada kepentingan hukum yang dilanggar, atau apakah ada perkembangan ke arah pergeseran hukum di masyarakat dan mengedepankan tujuan hukum, khususnya kemanfaatan hukum dengan mengkalkukasi resiko pengambilan keputusan secara cepat dan tepat.

\section{Faktor-faktor penyebab Pengguna Anggaran dibebankan tanggungjawab pidana}

Dalam UU No. 1 Tahun 2004, Pasal 18 ayat (2) c bahwa "Pejabat yang menandatangani dan/atau mengesahkan dokumen yang berkaitan dengan surat bukti yang menjadi dasar pengeluaran atas beban APBN/APBD bertanggung jawab atas kebenaran material dan akibat yang timbul dari penggunaan surat bukti dimaksud.

Dalam hal pertanggungjawaban hukum pejabat pengadaan barang dan jasa, penegak hukum seharusnya dapat membedakan jenis pertanggungjawaban dan kesalahan seseorang yang didakwa melakukan TPK, padahal bisa saja itu bukan perbuatan pidana, melainkan perbuatan yang memiliki pertanggungjawaban jabatan. Oleh sebab itu, penegak hukum harus cermat dalam membedakan mana kesalahan pribadi dan jabatan, guna memberikan keadilan yang hakiki.

Dalam pertanggungjawaban Pejabat PA/KPA memiliki dua jenis yaitu pertanggungjawaban jabatan dan pertanggungjawaban pribadi. "Pertanggungjawaban jabatan adalah tanggung jawab menurut hukum yang dibebankan kepada Negara/Pemerintah atas kesalahan atau akibat tindakan dari tindakan jabatan. Sedangkan pertanggung-jawaban pribadi adalah tanggung jawab secara pidana yang dibebankan kepada seseorang atas kesalahan atau akibat perbuatanya secara pribadi."

Dalam hukum administrasi, parameter tanggung jawab jabatan adalah asas legalitas (keabsahan) tindakan pejabat. Dalam hukum administrasi, persoalan legalitas tindakan pejabat berkaitan dengan pendekatan kekuasaan. Sedangkan tanggung jawab pribadi adalah tanggung jawab pidana, maka hal itu berkaitan dengan pendekatan fungsionaris atau pendekatan perilaku. Tanggung jawab pribadi berkenaan dengan maladministrasi dalam penggunaan wewenang maupun public service dengan kata maladminstrasi artinya pelayanan yang jelek. 
Terkait dengan faktor-faktor penyebab PA dibebankan tanggungjawab pidana, di samping teori dan azas-azas tersebut diatas, beberapa faktor pendukung yang menjadi penyebabnya adalah sebagai berikut:

1. Sumber daya manusia dikalangan penyidik TPK

Penyidik, dalam hal ini adalah penyidik Polri, kualitas SDM yang belum memadai. Padahal pada sisi lain untuk menangani kasus TPK diperlukan SDM yang memiliki kualitas dan pengalaman memadai. Akibat pendidikan yang kurang, muncul rasa rendah diri pada saat harus menyidik pihak tersangka yang dari segi pendidikan jauh lebih tinggi. Hal tersebut dikarenakan penyidik Polri hanya memahami mengenai prosedural penanganan TPK, tidak memahami mengenai substansial penanganannya terutama yang melibatkan Pejabat PA. TPK merupakan jenis pidana yang berbeda dengan tindak pidana lain pada umumnya, ada ciri khusus yang melekat pada pelaku tindak pidana tersebut.

2. Sistem penanganan perkara di kejaksaan 5-3-1

Dalam upaya penanganan perkara korupsi, sejak beberapa tahun terakhir Kejaksaan terus memperbaiki kinerjanya. Sehubungan dengan Kebijakan Penanganan Perkara Korupsi 5:3:1, yaitu penanganan 5 perkara korupsi di setiap Kejaksaan Tinggi, 3 perkara di setiap Kejaksaan Negeri dan 1 di setiap Cabang Kejaksaan Negeri.

Hal tersebut mendorong para Kepala Kejaksaan Tinggi, Kepala Kejaksaan Negeri, dan Kepala Cabang Kejaksaan Negeri menuntaskan "target" dalam bentuk berkas penyidikan TPK, akhirnya para Kepala Kejaksaan Tinggi, Kepala Kejaksaan Negeri, dan Kepala Cabang Kejaksaan Negeri "terjebak" dan hanya mengedepankan mengenai prosedural penanganan TPK, tidak mengedapankan atau memahami mengenai substansial penanganan TPK terutama yang melibatkan Pejabat PA.

3. Biaya pemberkasan pemeriksaan korupsi

Peraturan Menteri Keuangan Nomor 99/Pmk.02/2013 Tentang Standar Biaya Keluaran Tahun Anggaran 2014 mengatur tentang satuan biaya per kegiatan penanganan perkara pada instansi kejaksaan seluruh Indonesia. Untuk wilayah Kejaksaan Tinggi biaya penanganan dan penyelesaian perkara TPK adalah sebesar Rp 193.860.000,- (seratus sembilan puluh tiga juta delapan ratus enam puluh ribu rupiah), sedangkan untuk wilayah Kejaksaan Negeri/ Cabang Kejaksaan Negeri Wilayah III Sulawesi Tengah biaya penanganan dan penyelesaian perkara TPK adalah sebesar Rp 264.500.000 (dua ratus enam puluh empat juta lima ratus ribu rupiah).

Hal ini, juga menjadi faktor penyebab PA dibebankan tanggungjawab pidana, sebab para JPU tidak lagi memikirkan secara substantif tentang penanganan TPK, terutama yang melibatkan Pejabat PA. Namun hanya memikirkan prosedural penanganan TPK, sehingga penyerapan biaya kegiatan penanganan perkara TPK dapat terpenuhi. 


\section{PENUTUP}

PA tidak dapat secara mutatis mutandis atau serta merta didudukkan sebagai Tersangka/Terdakwa dalam perkara korupsi, sebab kesalahan jabatan, adalah perbuatan yang bertentangan dengan legalitas tindakan pejabat yang bertumpu pada wewenang, porsedur dan subtansi. Perbuatan Pejabat PA adalah merupakan perbuatan administrasi dan penggunaan pidana adalah Ultimum Remedium.

Tanggung jawab hukum atas Kuasa PA yang diberikan kepada PA yakni: a. Pertanggungjawaban PA tersebut, apakah sesuai amanat perundang-undangan yang diberikan kepadanya selaku KPA, atau tahapan dalam Keputusan Presiden No. 80 Tahun 2003 tentang Pengadaan Barang dan Jasa Pemerintah, (2) Adanya kewenangan terikat, dimana semua prosedur telah dilakukan, sehingga PA tidak ada alasan untuk tidak bisa melakukan. (3) Adanya ketelitian dalam mempertimbangkan hukumnya, apakah ada situasi darurat atau mendesak, sehingga PA melakukan perbuatan demikian, dan dari perbuatan tersebut, apakah ada atau tidak ada kepentingan hukum yang dilanggar, atau apakah ada perkembangan ke arah pergeseran hukum di masyarakat dan mengedepankan tujuan hukum, khususnya kemanfaatan hukum dengan mengkalkukasi resiko pengambilan keputusan secara cepat dan tepat. Faktor-faktor penyebab PA dibebankan tanggungjawab pidana, yakni (a) Sumber daya manusia dikalangan penyidik TPK, (b) Sistem penanganan perkara di Kejaksaan, (c) Biaya pemberkasan pemeriksaan Korupsi.

\section{DAFTAR PUSTAKA}

Achmad Ali, 2008, Menguak Realitas Hukum, Jakarta: Kencana Pranada Media.

Darwan Prinst, 2002, Pemberantasan Tindak Pidana Korupsi, Bandung: Citra Aditya Bakti.

Philipus M Hadjon, 2012, Hukum Administrasi dan Good Governance, Jakarta: Universitas Trisakti.

, 2011, Philipus M. Hardjon, tp, Tentang Wewenang, Surabaya: Universitas Airlangga.

Rusadi Kantaprawira, 1983, Hukum dan Kekuasaan, Yogyakarta: Universitas Islam Indonesia.

Nawi, R. 2015. Pengaruh Kebijakan Publik terhadap Kualitas Pelayanan, penguatan Kelembagaan dan Kinerja Organisasi Pemerintahan. Pleno Jure, 4(5), 42-55.

Sudarto, 1981, Tindak Pidana Korupsi di Indonesia, Semarang: Fakultas Hukum Universitas Diponegoro. 